"Investigation on the value relevance of accounting information: evidence from incorporated companies in the Singapore capital market"

$\begin{array}{ll} & \text { Basil Abeifaa Der } \\ & \text { Petr Polak (D) https://orcid.org/0000-0002-2434-4540 } \\ & \text { Masairol Masri }\end{array}$

Masairol Masri

Basil Abeifaa Der, Petr Polak and Masairol Masri (2016). Investigation on the

ARTICLE INFO value relevance of accounting information: evidence from incorporated companies in the Singapore capital market. Investment Management and Financial Innovations, 13(3), 9-21. doi:10.21511/imfi.13(3).2016.01

DOI http://dx.doi.org/10.21511/imfi.13(3).2016.01

RELEASED ON Tuesday, 23 August 2016

JOURNAL

"Investment Management and Financial Innovations"

FOUNDER

LLC "Consulting Publishing Company "Business Perspectives"

NUMBER OF REFERENCES

0

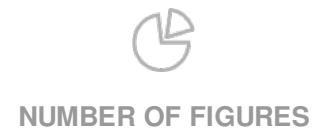

0

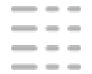

NUMBER OF TABLES

0

(C) The author(s) 2022. This publication is an open access article. 
Basil Abeifaa Der (Brunei), Petr Polak (Brunei), Masairol Masri (Brunei)

\title{
Investigation on the value relevance of accounting information: evidence from incorporated companies in the Singapore capital market
}

\begin{abstract}
The purpose of this study is to investigate the relative, incremental and the systematic changes in value relevance of the accounting information. This study also attempts to investigate the effect of earnings management on the value relevance of accounting information. It basically uses Ohlson's (1995) valuation model to test the conceptual framework.

The findings of this paper reveal that book value is more value relevant and incremental followed by earnings and, then, cash flow. Cash flow, however, performs a lesser valuation role. The results also show that combined book value and earnings are more value relevant than combined book value and cash flow. As a third contribution, the paper also finds that the value relevance of some accounting variables has increased over time, while others showed no evidence of their inclined or declined patterns in the value relevance of accounting information. Finally, the paper finds that earnings management has no effect on the value relevance of accounting information. Further analyses suggest that earnings management is opportunistic in the short run, but efficient in the long run, when firms are small or have high asset turnover.
\end{abstract}

Keywords: value relevance, capital market, book values, earnings, cash flows, gearing, earnings management. JEL Classification: M40, M41, G14, G32.

\section{Introduction}

Accounting measures are important components of determining the value of a firm. From empirical findings, accounting measures such as book value and earnings have an association with equity shares, hence, are used in firm valuation. Studies on these variables pointed out that they contained information which is embedded in the market value of entities, hence, changes stock price. However, Amir and Lev (1996) remarked that book values and earnings do not have significant association with stock prices. Kwon (2009) also remarked that earnings do not have a statistical association with stock market prices. Healy and Palepu (2001) remarked that accounting information impacts on stock prices in effective stock markets: the higher the quality of accounting information, the more useful it is to investors to make informed decisions. Academic literature suggests that the true measure of value of an entity is "shareholder wealth maximization". Hence, investors measure their wealth by virtue of the market value of ordinary shares that they hold. The concept of value relevance in accounting is, therefore, an attempt to link accounting numbers to the market value of ordinary shares. Value relevance is defined as the ability of accounting measures to capture and reflect information that affects firm value (Hung, 2001; Francis and Schipper, 1999). This is determined by the statistical association between accounting measures and stock market prices.

(C) Basil Abeifaa Der, Petr Polak, Masairol Masri, 2016. Basil Abeifaa Der, University of Brunei Darussalam, Brunei.

Petr Polak, Dr., Associate Professor of Finance, University Brunei Darussalam, School of Business and Economics, Brunei.

Masairol Masri, University of Brunei Darussalam, Brunei.
This paper investigates the value relevance of accounting information among Singapore companies over the past two decades, during which substantial developments occurred in their accountancy profession. It also investigates the effect of earnings management on the value relevance of accounting information. It is primarily motivated by the developments that have occurred in the accountancy profession in terms of their regulatory bodies and standards, contradictory empirical evidence in the value relevance literature and the dearth information in terms of studies pertaining to the value relevance of accounting information on their capital market. It investigates value relevance of accounting information in a broader faculty rather than providing analogy between the accountancy developments in Singapore and the value relevance of accounting information.

The empirical results of this paper reveal that book value is value relevant and incremental followed by earnings and, then, cash flow. However, cash flow is weakly value relevant, because the sign of its coefficients differs from the expected. The results also indicate that combined book value and earnings are more value relevant than combined book value and cash flow. The results also showed that the value relevance of some accounting variables have increased over time, while others showed no evidence in the inclined or declined patterns in the value relevance of accounting information. The results also indicate that earnings management has no effect on the value relevance of accounting information which is consistent with Fattahi, MoeninAddin and Abtahi (2014), but contrary to the findings of Habib (2004). This may be as a result of 
the good corporate governance practices that exist in Singapore. Further analyses show that earnings management is opportunistic in the short run, but efficient in the long run.

The rest of the paper proceeds as follows. Section 1 details the background of the accountancy developments in Singapore. Section 2 outlines previous related literature that examines the subject matter and the research hypotheses. Section 3 details the methodology of this study and the sample collection procedures. The fourth section discusses the empirical results, while final section concludes the study.

\section{Background of the accountancy developments in Singapore}

Prior to 2002, the Institute of Certified Public Accountants of Singapore was the standard setter for all companies incorporated in Singapore. The institute became a member of the International Federation of Accountants (IFAC) in 1977. The Institute issued a Statement of Recommended Accounting Practices in 1977 which provided companies for guidance with reference to compliance with the disclosure requirements in the Singapore Companies Act 1967. Accounting standards were issued as Statement of Accounting Standards (SASs) and Statement of Recommended Accounting Practices (RAPs). The SAS are not legally binding, but compliance is expected.

In 2002, the Council on Corporate Disclosure and Governance (CCDG) was created by the Singapore to replace its predecessor, the Institute of Public Accountants of Singapore as an accounting standard setter for all companies incorporated in Singapore (Deloitte IAS Plus, Singapore).

On the $1^{\text {st }}$ of November 2007, the CCDG was replaced by its successor the Accounting Standards Council (ASC). The ASC is tasked with prescribing accounting standards for companies, charities, cooperative societies and societies. The Accounting Standards Act was passed on the $27^{\text {th }}$ of August 2007. The Singapore Government believes that the standards aid in intercompany comparison of financial statements and transparency. The actors for the monitoring and enforcement of accounting standards are the Accounting and Corporate Regulatory Authority (ACRA), Commissioner of Charities, Registrar of Co-operative Societies and Registrar of Societies for companies, charities, cooperative societies and societies, respectively (Deloitte IAS Plus, Singapore). As of November 2008, the ASC issued a set of accounting standards and interpretation that are identical to the current IFRS. Currently Singapore adopts the International Financial Reporting Standards with some modification to suit the Singapore context. Singapore has adopted all IFRS with the exception of IFRIC 2 members' shares in co-operative entities and similar instruments. The standards in Singapore are called Singapore Financial Reporting Standards (SFRS). In January 2018, Singapore Accounting Standards are expected to fully converge with IFRS (IFRS Foundation, 2014).

\section{Literature review and hypotheses}

\section{The role of book value, cash flow and earnings in equity valuation}

Prior research points to the fact that book value, cash flow and earnings are value relevant (see Kwon, 2009). Book values possess greater explanatory power than cash flows and earnings (Andriantomo and Yudianti, 2013; Pathirawasam, 2013; Kwon, 2009). Other studies remarked that cash flows are more value relevant than earnings (Choi and Jang, 2006; Kwon, 2009). Studies such as Collins, Maydew and Weiss (1997) highlighted the superiority of the value relevance of earnings. We believe that investors' decisions are likely to be principally based on the assets and liabilities of a firm and least based on earnings, because earnings are likely to be manipulated and also negative earnings deteriorate accounting value relevance. This leads to our first hypothesis.

H1a. Book values are value relevant, followed by cash flows and, then, earnings.

The role of combined book value and cash flow and combined book value and earnings in equity valuation

Combined book values and cash flows have value relevance (Kwon, 2009). Combined book values and earnings also have value relevance (Mustapha and Jahfer, 2013; Andriantomo and Yudianti, 2013). Kwon (2009) noted that combined value relevance of book values and cash flows is more than that of book values and earnings. We believe that the model with cash flow would produce better results than the model with earnings. This leads to our second hypothesis (stated in alternative form).

H1b. Combined value relevance between book values and cash flows is greater than that of book values and earnings.

\section{Incremental value relevance of accounting information}

Relative value relevance is a concept which implies that one measure of value relevance alone provides greater information content than another measure. Conversely, the incremental value relevance implies that one measure provides information incremental to that provided by another. Nilsson (2011) argued 
that an accounting number may be value relevant, but lack information content. However, one accounting measure provides incremental information content beyond another (see Hejazi, Jafari and Karimi, 2011; Collins et al., 1997). Book values are more incremental than earnings (Andriantomo and Yudianti, 2013). Daraghma (2010) highlighted that earnings provide incremental information content beyond operating cash flows, but operating cash flows does not provide information beyond earnings. However, in this study we expect book values to provide more information content followed by cash flows and, then, earnings. This leads to our next hypothesis.

H1c. Book values provide more information content followed by cash flow and, then, earnings.

\section{Inclined or declined patterns in the value relevance of accounting information}

Whiles some studies remarked that the value relevance of accounting information has increased over time (Collins et al., 1997), others were to the contrary (Brown, Lo and Lys, 1999). Collins, Maydew and Weiss (1997) researched into the changes in value relevance of book values and earnings over a period of forty (40) years. They commented that value relevance of book values, earnings and combined book values and earnings has increased over time. Francis and Schipper (1999) explored the notion that accounting numbers have lost their value relevance. They examined the impact of earnings and book values in predicting stock market prices of equity with reference to their explanatory powers. They reported that the value relevance of earnings has decreased over time, while the value relevance of balance sheet information has increased over time. They also reported that there is no difference between high technology firms and low technology firms with regards to value relevance. Andriantomo and Yudianti (2013) noted that there is no evidence in the inclined or declined patterns in the value relevance of accounting information. We believe that the changes in the accountancy practices and institutions in Singapore would add more meaning to financial reporting figures, consequently, improving on their value relevance. We expect the value relevance of all financial reporting variables to increase over time. This leads to our next two hypotheses.

H2a. The value relevance of book value, cash flows and earnings has increased over time.

$H 2 b$. Combined value relevance of book values and cash flow and book values and earnings has increased over time.

\section{The value relevance of accounting information and earnings management}

Efficient earnings management results in the maximization of shareholder wealth. When earnings are managed efficiently, it is done in the interest of management. It also makes earnings more informative by communicating private information (Scott, 2000). Rezaei (2012) investigated into efficient or opportunistic earnings management with particular interest in corporate governance and firm size. He showed that earnings management was more of efficient rather than opportunistic in companies listed on the Tehran Stock Exchange (TSE). Jiraporn et al. (2008) investigated into opportunistic and efficient earnings management. Their findings showed that earnings management does not occur at a greater magnitude in firms that have high agency cost. Their results showed that earnings management has a positive relationship with firm value, hence, efficient. Deegan (2009) remarked that the efficiency perspective highlights how superiors make accounting choices to show a true and fair representation of a firm's performance. We believe that there is a higher tendency for companies to manage earnings opportunistically than informatively because of the self-interest of agents, as highlighted by the agency conflict. This leads to our next hypothesis.

\section{H3. Earnings are managed opportunistically rather} than efficiently.

\section{Valuation models}

This study primarily uses the Ohlson's (1995) model. The model is widely used in value relevance studies (see Francis and Schipper, 1999; Kwon, 2009). Ohlson's (1995) model has a theoretically proven base, hence, adds to the motivation of its usage. The model expresses value as a function of book value and earnings.

$M P S_{i t}=\alpha_{0}+\alpha_{1} B V P_{i t}+\alpha_{2} E P S_{i t}+\varepsilon_{i t}$.

The value relevance of accounting information is measured by the adjusted R-square: the explanatory power of the model. Cash flow is added to the model, because the paper predicts that it provides additional information and can be an alternate valuation model.

To investigate the value relevance of the individual accounting variables (H1a), the models are decomposed and are specified as:

$$
\begin{aligned}
& M P S_{i t}=\alpha_{0}+\alpha_{1} B V P_{i t}+\varepsilon_{i t}, \\
& M P S_{i t}=\alpha_{0}+\alpha_{1} C F S_{i t}+\varepsilon_{i t}, \\
& M P S_{i t}=\alpha_{0}+\alpha_{1} E P S_{i t}+\varepsilon_{i t},
\end{aligned}
$$


where $B V P=$ Book value per share; $C F S=$ Operating cash flow per share; . = Earnings per share.

To investigate the value relevance of combined book value and cash flow and combined book value and earnings ( $\mathrm{H} 1 \mathrm{~b})$, the models are specified as:

$M P S_{i t}=\alpha_{0}+\alpha_{1} B V P_{i t}+\alpha_{2} C F S_{i t}+\varepsilon_{i t}$,

$M P S_{i t}=\alpha_{0}+\alpha_{1} B V P_{i t}+\alpha_{2} E P S_{i t}+\varepsilon_{i t}$.

To investigate the incremental information content of book values, earnings and cash flows ( $\mathrm{H} 1 \mathrm{c})$, the incremental $R$ square are computed as follows:

$B V P / C F S=$ Adjusted $R_{B V P \& C F S}^{2}-$ Adjusted $R_{C F S}^{2},(6)$

$C F S / B V P=$ Adjusted $R_{B V P \& C F S}^{2}-$ Adjusted $R_{B V P}^{2},(7)$

$B V P / E P S=$ Adjusted $R_{B V P \& E P S}^{2}-$ Adjusted $R_{E P S}^{2},(8)$

$E P S / B V P=$ Adjusted $R_{B V P \& E P S}^{2}-$ Adjusted $R_{B V P .}^{2}(9)$

To investigate the inclined or declined patterns in the value relevance of book values, earnings and cash flows overtime, we used the following equations. We regressed the adjusted R-square of equations (1) to (5) on a time dummy variable.

$R_{t}^{2}$ (Book values per share $)=\alpha_{0}+\alpha_{1}$ TIME $+\varepsilon_{t},(10)$

$R_{t}^{2}$ (Earnings per share $)=\alpha_{0}+\alpha_{1}$ TIME $+\varepsilon_{t}$.,

$R_{t}^{2}($ Cash flow per share $)=\alpha_{0}+\alpha_{1}$ TIME $+\varepsilon_{t}$.

To investigate the inclined or declined patterns in the value relevance of combined book values and earnings, and combined book values and cash flows overtime, we regressed the adjusted $\mathrm{R}$ square on the time variable.

$R_{t}^{2}$ (Combined book values and earnings $)=\alpha_{0}+\alpha_{1}$ $T I M E+\varepsilon_{t}$,

$R_{t}^{2}$ (Combined of book values and cash flow) $\alpha_{0}+\alpha_{1}$ $T I M E+\varepsilon_{t}$.

TIME $=1,2,3 \ldots \ldots 21$ for the period 1994 to 2014. This method of determining changes in value relevance over time is applied by Andriantomo and Yudianti (2013) and Brown, Lo and Lys (1999).

To investigate hypothesis $3 \mathrm{a}$, we develop the following model:

$M P S_{t}=\alpha_{0}+\alpha_{1} B V P+\alpha_{2} E P S+\alpha_{3} B V P * E M+\alpha_{4}$

$E P S * E M+\alpha_{5} E M+\alpha_{6} R O A+\varepsilon$,

where $E M=$ earnings management.

Sample and variable definitions. The sample period is from 1994 to 2013 comprising 389 firms. It is a panel data comprising 5116 firm year observations. The information about the companies were collected from DataStream database version 5.1. We have limited our sample to this period because of the availability of data. Companies selected should have been incorporated in Singapore. Uniformity is required for the interpretation of results. We excluded financial firms from our sample because of their unique financial reporting requirement and also high leverage which is normal for these firms and does not have the same meaning for non-financial firms, where high gearing may mean distress. Companies with insufficient data were also deleted. Companies listed on the catalyst board were also deleted, because they do not meet the quantitative criteria that are required to be listed on the main board. Outliers were also deleted from the sample. Companies whose reporting currency is a foreign currency were also deleted from the sample. The yearly distribution of the sample companies is shown below in Table 1 .

Table 1. Yearly distribution of companies

\begin{tabular}{|c|c|}
\hline Year & Number \\
\hline 1994 & 45 \\
\hline 1995 & 58 \\
\hline 1996 & 84 \\
\hline 1997 & 92 \\
\hline 1998 & 108 \\
\hline 1999 & 108 \\
\hline 2000 & 158 \\
\hline 2001 & 192 \\
\hline 2002 & 225 \\
\hline 2003 & 256 \\
\hline 2004 & 274 \\
\hline 2005 & 293 \\
\hline 2006 & 318 \\
\hline 2007 & 334 \\
\hline 2008 & 345 \\
\hline 2009 & 357 \\
\hline 2010 & 371 \\
\hline 2011 & 371 \\
\hline 2012 & 378 \\
\hline 2013 & 380 \\
\hline 2014 & 379 \\
\hline & \\
\hline & \\
\hline
\end{tabular}

Variables are estimated as follows:

$M P S$ is measured three months after balance sheet date (Datastream code: $\mathrm{P}$ ).

EPS is measured as income after tax and extraordinary items (Datastream code: EPS).

CFS represents the net cash receipts and disbursements resulting from the operations of the company (Worldscope code: WC04860) divided by the number of shares in issue.

1. BVP represents book value at a company's fiscal year end (Worldscope code: WC05476).

2. We estimate earnings management by adopting the abnormal non-core earnings method 
implored by Qui (2004) and Chen and Yuan (2001). Abnormal non-core earnings are used to study the relationship between value relevance of accounting information and earnings management, because it is a gap identified in the literature. Previous studies used other earnings management measures such as earnings management by accruals. However, accrual models are criticized for misclassifying nondiscretionary as discretionary accruals (Pae, 2005). Core earnings and non-core earnings in year $\mathrm{t}$ are calculated as follows:

$C E_{t}=\left(\right.$ Sales $_{t}-\left(\right.$ COGS $\left.\left._{t}+E_{X P_{t}}\right)\right)$,

$N C E_{t}=\left(E B T_{t}-C E_{t}\right) / T A_{t-1}$, where: $C E=$ core earnings; $C O G S=$ cost of goods sold; $E X P=$ Operating, administrative, selling and distribution expenses and finance charges; $T A_{t-1}=$ Lagged total assets; $N C E=$ non-core earnings; $E B T=$ earnings before tax.

Since not all non-core earnings can be regarded as earnings management, Qui (2004) adopted an industry approach in estimating abnormal non-core earnings: the earnings management component of earnings. Following Qui (2004), we calculate abnormal non-core earnings in year $\mathrm{t}$ as follows:

$A N C E_{t}=N C E_{t}-$ Median $\left(N C E_{t}\right)$,

where: $A N C E=$ abnormal non-core earnings.

Table 2. Descriptive statistics for the sample

\begin{tabular}{|l|c|c|c|c|}
\hline \multicolumn{1}{|c|}{ Variable } & Mean & Standard deviation & Minimum & Maximum \\
\hline MPS & 1.0670 & 2.3940 & .001 & 43.477 \\
\hline BVP & 0.8227 & 1.5692 & -6.567 & 14.775 \\
\hline CFS & 0.0910 & .4404 & -6.0442 & 10.2811 \\
\hline EPS & 0.1220 & .3805 & .01 & 13.4 \\
\hline EARNINGS MGT & 0.0012 & .1132 & -6.1546 & 2.5202 \\
\hline
\end{tabular}

Table 2 presents the descriptive statistics for our sample. The mean, standard deviation, minimum and maximum values are also reported. Table 3 shows the Pearson correlation matrix for the entire sample.
Correlation refers to the degree of association between variables. While most of them are significant, on the whole, they are not of size to suggest that there is the presence of multi-collinearity problem.

Table 3. Pearson correlation matrix for the variables

\begin{tabular}{|c|c|c|c|c|c|c|c|c|}
\hline & MPS & BVP & EPS & CFS & BVP*EM & EPS*EM & EM & ROA \\
\hline MPS & 1.0000 & & & & & & & \\
\hline BVP & $0.4985^{*}$ & 1.0000 & & & & & & \\
\hline EPS & $0.5687^{\star}$ & $0.6970^{*}$ & 1.0000 & & & & & \\
\hline CFS & $0.2866^{*}$ & $0.2181^{*}$ & $0.2176^{*}$ & 1.0000 & & & & \\
\hline BVP*EM & 0.0166 & 0.0235 & 0.0222 & $0.3582^{*}$ & 1.0000 & & & \\
\hline EPS*EM & $-0.0486^{*}$ & -0.0163 & $0.0474^{*}$ & $0.0364^{\star}$ & $0.3021^{*}$ & 1.0000 & & \\
\hline EM & -0.0193 & $-0.0586^{\star}$ & $-0.0437^{\star}$ & $0.2245^{\star}$ & $0.6558^{\star}$ & $0.2097^{\star}$ & 1.000 & \\
\hline ROA & -0.0002 & $-0.0483^{\star}$ & $0.0529^{*}$ & 0.0110 & -0.0013 & -0.0004 & -0.0147 & 1.0000 \\
\hline
\end{tabular}

Note: * Significant at $5 \%$ level. Figures in bold font do not pertain to any of the models.

\section{Empirical analyses}

Table 4. Analyses of the value relevance of book value, earnings and cash flows: simple linear regression

\begin{tabular}{|c|c|c|c|c|c|c|}
\hline \multirow{3}{*}{ Year } & \multicolumn{2}{|c|}{ Model 1} & \multicolumn{2}{|c|}{ Model 2} & \multicolumn{2}{|c|}{ Model 3} \\
\hline & \multicolumn{2}{|c|}{$M P S_{i t}=\alpha_{0}+\alpha_{1} B V P_{i t}+\varepsilon_{i t}$} & \multicolumn{2}{|c|}{$M P S_{i t}=\alpha_{0}+\alpha_{1} C F S_{i t}+\varepsilon_{i t}$} & \multicolumn{2}{|c|}{$M P S_{i t}=\alpha_{0}+\alpha_{1} E P S_{i t}+\varepsilon_{i t}$} \\
\hline & $\operatorname{Adj} R^{2}$ & $\alpha_{1}$ & $\operatorname{Adj} R^{2}$ & $a_{1}$ & $\operatorname{Adj} R^{2}$ & $a_{1}$ \\
\hline 1994 & 0.8597 & $\begin{array}{c}1.2873 \\
(14.8225)^{\star \star \star}\end{array}$ & -0.0989 & $\begin{array}{c}-0.1512 \\
(-0.1010)\end{array}$ & 0.6964 & $\begin{array}{c}16.7689 \\
(3.3195)^{\star \star \star}\end{array}$ \\
\hline 1995 & 0.3782 & $\begin{array}{c}1.3514 \\
(3.2248)^{\star \star \star}\end{array}$ & -0.0097 & $\begin{array}{c}-0.5713 \\
(-0.7611)\end{array}$ & 0.5941 & $\begin{array}{c}15.2989 \\
(8.2659)^{\star * \star}\end{array}$ \\
\hline 1996 & 0.0800 & $\begin{array}{c}0.9921 \\
(2.8367)^{\star \star \star}\end{array}$ & 0.0288 & $\begin{array}{c}2.0024 \\
(1.8441)^{*}\end{array}$ & 0.8921 & $\begin{array}{c}13.4745 \\
(23.7321)^{\star \star \star}\end{array}$ \\
\hline 1997 & 0.1694 & $\begin{array}{c}1.2013 \\
(4.2824)^{\star \star \star}\end{array}$ & 0.0168 & $\begin{array}{c}1.1382 \\
(1.5650)\end{array}$ & 0.8871 & $\begin{array}{c}12.5290 \\
(23.1335)^{\star \star \star}\end{array}$ \\
\hline 1998 & 0.5167 & $\begin{array}{c}1.0119 \\
(2.8274)^{\star \star \star}\end{array}$ & 0.1834 & $\begin{array}{c}3.2431 \\
(1.4267)\end{array}$ & 0.1734 & $\begin{array}{c}6.1932 \\
(4.0391)^{\star \star \star}\end{array}$ \\
\hline 1999 & 0.6266 & $\begin{array}{c}1.5104 \\
(3.7080)^{\star \star \star}\end{array}$ & 0.0593 & $\begin{array}{c}1.5548 \\
(1.0315)\end{array}$ & 0.8491 & $\begin{array}{c}5.9032 \\
(6.7486)^{\star \star \star}\end{array}$ \\
\hline
\end{tabular}


Table 4 (cont.). Analyses of the value relevance of book value, earnings and cash flows: simple linear regression

\begin{tabular}{|c|c|c|c|c|c|c|}
\hline \multirow{3}{*}{ Year } & \multicolumn{2}{|c|}{ Model 1} & \multicolumn{2}{|c|}{ Model 2} & \multicolumn{2}{|c|}{ Model 3} \\
\hline & \multicolumn{2}{|c|}{$M P S_{i t}=\alpha_{0}+a_{1} B V P_{i t}+\varepsilon_{i t}$} & \multicolumn{2}{|c|}{$M P S_{i t}=\alpha_{0}+\alpha_{1} C F S_{i t}+\varepsilon_{i t}$} & \multicolumn{2}{|c|}{$M P S_{i t}=\alpha_{0}+\alpha_{1} E P S_{i t}+\varepsilon_{i t}$} \\
\hline & $\operatorname{Adj} R^{2}$ & $a_{1}$ & $\operatorname{Adj} R^{2}$ & $a_{1}$ & $\operatorname{Adj} R^{2}$ & $a_{1}$ \\
\hline 2000 & 0.6861 & $\begin{array}{c}1.9635 \\
(9.4964)^{\star \star \star}\end{array}$ & 0.2117 & $\begin{array}{c}5.1514 \\
(6.0372)^{\star \star \star}\end{array}$ & 0.5796 & $\begin{array}{c}7.9768 \\
(4.8106)^{\star \star \star}\end{array}$ \\
\hline 2001 & 0.4385 & $\begin{array}{c}0.9968 \\
(11.7674)^{\star * \star}\end{array}$ & 0.0422 & $\begin{array}{c}1.1520 \\
(2.9585)^{\star \star *}\end{array}$ & 0.3864 & $\begin{array}{c}1.4234 \\
(8.4212)^{\star \star \star}\end{array}$ \\
\hline 2002 & 0.6063 & $\begin{array}{c}1.0268 \\
(5.1348)^{* * *}\end{array}$ & 0.1900 & $\begin{array}{c}3.6257 \\
(2.2952)^{* *}\end{array}$ & 0.5716 & $\begin{array}{c}4.1290 \\
(4.0729)^{\star \star \star}\end{array}$ \\
\hline 2003 & 0.5443 & $\begin{array}{c}0.8314 \\
(3.2214)^{\star \star \star}\end{array}$ & 0.1757 & $\begin{array}{c}2.3085 \\
(2.1630)^{\star *}\end{array}$ & 0.2662 & $\begin{array}{c}0.9943 \\
(3.5264)^{\star \star \star}\end{array}$ \\
\hline 2004 & 0.5933 & $\begin{array}{c}1.0973 \\
(6.2703)^{\star \star \star}\end{array}$ & 0.0135 & $\begin{array}{c}0.4565 \\
(2.0238)^{\star *}\end{array}$ & 0.8003 & $\begin{array}{c}12.9508 \\
(5.1434)^{\star \star \star}\end{array}$ \\
\hline 2005 & 0.5517 & $\begin{array}{c}1.0573 \\
(18.0179)^{\star \star \star}\end{array}$ & 0.1960 & $\begin{array}{c}-3.0420 \\
(-1.7075)^{\star}\end{array}$ & 0.4981 & $\begin{array}{c}5.2394 \\
(2.1107)^{\star *}\end{array}$ \\
\hline 2006 & 0.7136 & $\begin{array}{c}1.2122 \\
(8.1201)^{\star \star \star}\end{array}$ & 0.1917 & $\begin{array}{c}1.1402 \\
(2.0028)^{\star \star}\end{array}$ & 0.4249 & $\begin{array}{c}10.4101 \\
(5.0954)^{\star \star \star}\end{array}$ \\
\hline 2007 & 0.7333 & $\begin{array}{c}1.1654 \\
(9.0461)^{\star \star \star}\end{array}$ & 0.1579 & $\begin{array}{c}7.4666 \\
(0.7379)\end{array}$ & 0.5468 & $\begin{array}{c}0.5501 \\
(4.0451)^{\star \star \star}\end{array}$ \\
\hline 2008 & 0.6810 & $\begin{array}{c}1.2805 \\
(2.7873)^{\star * \star}\end{array}$ & 0.3213 & $\begin{array}{c}2.0122 \\
(2.2082)^{\star \star}\end{array}$ & 0.5548 & $\begin{array}{c}8.4847 \\
(6.1431)^{\star \star \star}\end{array}$ \\
\hline 2009 & 0.6145 & $\begin{array}{c}0.6096 \\
(20.9755)^{\star \star \star}\end{array}$ & 0.2531 & $\begin{array}{c}0.9476 \\
(7.7704)^{\star \star \star}\end{array}$ & 0.6422 & $\begin{array}{c}4.3974 \\
(5.4888)^{\star \star \star}\end{array}$ \\
\hline 2010 & 0.7308 & $\begin{array}{c}1.1330 \\
(5.0692)^{\star * \star}\end{array}$ & 0.2300 & $\begin{array}{c}2.2934 \\
(1.3247)\end{array}$ & 0.4499 & $\begin{array}{c}0.8121 \\
(3.2868)^{\star \star \star}\end{array}$ \\
\hline 2011 & 0.6026 & $\begin{array}{c}0.6715 \\
(6.3629)^{\star \star \star}\end{array}$ & 0.4004 & $\begin{array}{c}1.6441 \\
(1.9888)^{\star \star}\end{array}$ & 0.4518 & $\begin{array}{c}0.7898 \\
(5.6985)^{\star \star \star}\end{array}$ \\
\hline 2012 & 0.5991 & $\begin{array}{c}0.4372 \\
(6.2687)^{\star * \star}\end{array}$ & 0.4555 & $\begin{array}{c}2.3113 \\
(4.2772)^{\star \star \star}\end{array}$ & 0.6847 & $\begin{array}{c}5.3251 \\
(5.9742)^{\star \star \star}\end{array}$ \\
\hline 2013 & 0.6011 & $\begin{array}{c}0.8040 \\
(23.8535)^{\star \star \star}\end{array}$ & 0.4345 & $\begin{array}{c}3.4181 \\
(4.1744)^{\star \star \star}\end{array}$ & 0.6278 & $\begin{array}{c}7.3951 \\
(6.2831)^{\star \star \star}\end{array}$ \\
\hline 2014 & 0.6242 & $\begin{array}{c}0.5277 \\
(6.7443)^{\star \star \star}\end{array}$ & 0.3101 & $\begin{array}{c}1.0644 \\
(1.4485)\end{array}$ & 0.6489 & $\begin{array}{c}6.9713 \\
(4.7754)^{\star \star \star}\end{array}$ \\
\hline Pooled (1994-2014) & 0.4964 & $\begin{array}{c}1.0652 \\
(20.02)^{\star \star \star}\end{array}$ & 0.0819 & $\begin{array}{c}1.5524 \\
(4.73)^{\star \star \star}\end{array}$ & 0.3233 & $\begin{array}{c}1.2730 \\
(39.81)^{\star \star \star}\end{array}$ \\
\hline
\end{tabular}

Notes: $* * *, * *, *$ significant at $1 \%, 5 \%$ and $10 \%$, respectively. Numbers in prentices are t-values.

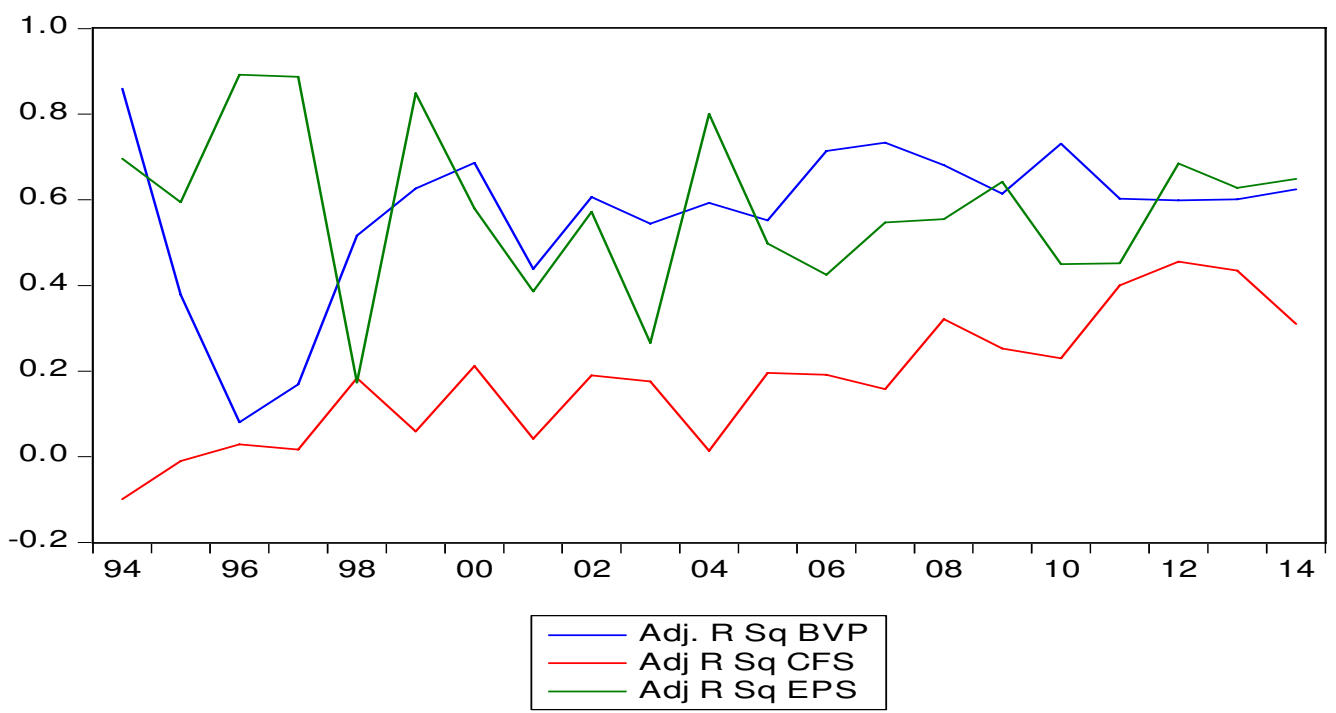

Fig. 1. Graphical view of the value relevance of book value, cash flow and earnings

Table 4 presents the OLS regression results which are used to test the value relevance of book values, cash flow and earnings individually to stock prices. Book value explained about $49.64 \%$ of stock price variance in pooled data. Yearly data showed that book value is a value relevant variable, as it explained a fraction of the variation in stock prices for all the twenty one (21) years under study. The lowest adjusted R-square recorded is 8\% in 1996 and the highest adjusted R-square recorded is 
$85.97 \%$ in 1994. All the coefficients of the regression model are positive which is expected. Book value is, therefore, a value relevant variable which is consistent with the findings of Kwon (2009), Pathirawasam (2013), King and Langli (1998), Andriantomo and Yudianti (2013) and Bernard (1993), but contrary to the findings of Amir and Lev (1996). The pooled regression result showed that cash flows explained about $8.19 \%$ of stock price variation. Yearly data showed that cash flows explained a fraction of stock price from 1996 to 2014. However, the fraction of variance of stock price explained by cash flow is very marginal (less than 10\%) in 1996, 1997, 1999, 2001, and 2004. In 1994 and 1995, cash flow recorded an adjusted Rsquare of $-9.89 \%$ and $-0.97 \%$, respectively, and a negative beta coefficient for the years 1994, 1995 and 2005, which was not expected. The above analyses reveal that cash flow is weakly value relevant and may not be a good substitute in a valuation model, as reported by Kwon (2009). The pooled regression result showed that earnings explained about $32.33 \%$ of stock price variance. Yearly data showed that earnings explained a portion of the variation in stock prices for all years under study. The highest R-square recorded was $89.21 \%$ in 1996 and the lowest R-square recorded was $17.34 \%$ in 1994 . Beta coefficients for all the years were positive which is expected. Earnings are, therefore, a value relevant variable which is consistent with the findings of Pathirawasam (2013), Andriantomo and Yudianti (2013), Collins,
Maydew and Weiss (1997), King and Langli (1998) and Ohlson (1995), but contrary to the findings of Amir and Lev (1996) and Kwon (2009). Hypothesis 1a states that book values are value relevant followed by cash flows and, then, earnings. Figure 1 compares the value relevance of book value, cash flow and earnings to find out the most value relevant variable. A graphical analysis is employed in this study to complement the tables, because it is more appealing to the eye. Table 4 and Figure 1, therefore, present that the adjusted $\mathrm{R}$ squared of book values are greater than cash flows for the years under study which is consistent with the findings of Kwon (2009). The adjusted R-square of earnings is greater than that of cash flow which is contrary to the findings of Choi and Jang (2006) and Kwon (2009). The adjusted R-square of book values is greater than earnings in 1994, 1995, 1998, 2000, 2001, 2002, 2003, 2005, 2006, 2007, 2008, 2010, 2011 and 2014. The pooled regression results show that book value is more value relevant than earnings which is consistent with the findings of Pathirawasam (2013), Pervan and Bartulovic (2014) and contrary to the findings of Collins Maydew and Weiss (1997). The pooled regression showed that book values, earnings and cash flows significantly explained about $49.64 \%, 32.33 \%$ and $8.19 \%$ of stock price variance, respectively. Book values are, therefore, value relevant, followed by earnings and, then, cash flows. Cash flow is, however, weakly value relevant. Hypothesis H1a is, therefore, rejected.

Table 5. Analyses of the value relevance of combined book value and earnings and combined book value and cash flow: multiple linear regression

\begin{tabular}{|c|c|c|c|c|c|c|}
\hline \multirow{3}{*}{ Year } & \multicolumn{3}{|c|}{ Model 4} & \multicolumn{3}{|c|}{ Model 5} \\
\hline & \multicolumn{3}{|c|}{$M P S_{i t}=a_{0}+a_{1} B V P_{i t}+a_{2} C F S_{i t}+\varepsilon_{i t}$} & \multicolumn{3}{|c|}{$M P S_{i t}=a_{0}+a_{1} B V P_{i t}+a_{2} E P S_{i t}+\varepsilon_{i t}$} \\
\hline & $\operatorname{Adj} R^{2}$ & $a_{1}$ & $a_{2}$ & $\operatorname{Adj} R^{2}$ & $a_{1}$ & $a_{2}$ \\
\hline 1994 & 0.4486 & $\begin{array}{c}1.3135 \\
(3.3057)^{\star \star \star}\end{array}$ & $\begin{array}{c}-1.3160 \\
(-1.1774)\end{array}$ & 0.8037 & $\begin{array}{c}0.8001 \\
(4.5909)^{\star \star \star}\end{array}$ & $\begin{array}{c}6.2819 \\
(2.3109)^{\star \star}\end{array}$ \\
\hline 1995 & 0.4533 & $\begin{array}{c}1.8343 \\
(3.0457)^{\star \star \star}\end{array}$ & $\begin{array}{c}-0.3606 \\
(-0.6151)\end{array}$ & 0.6054 & $\begin{array}{c}0.3355 \\
(1.5115)\end{array}$ & $\begin{array}{c}13.4358 \\
(6.1009)^{\star \star \star}\end{array}$ \\
\hline 1996 & 0.0887 & $\begin{array}{c}0.8914 \\
(2.5016)^{\star \star}\end{array}$ & $\begin{array}{c}1.4278 \\
(1.3262) \\
\end{array}$ & 0.8979 & $\begin{array}{c}0.4259 \\
(2.1934)^{\star \star}\end{array}$ & $\begin{array}{c}13.2017 \\
(23.3198)^{\star \star \star}\end{array}$ \\
\hline 1997 & 0.1615 & $\begin{array}{c}1.1612 \\
(3.9383)^{\star \star \star}\end{array}$ & $\begin{array}{c}0.3255 \\
(0.4633)\end{array}$ & 0.8978 & $\begin{array}{c}0.5279 \\
(2.2319)^{\star *}\end{array}$ & $\begin{array}{c}12.1820 \\
(39.8878)^{\star * \star}\end{array}$ \\
\hline 1998 & 0.5365 & $\begin{array}{c}0.9135 \\
(3.4467)^{\star \star \star}\end{array}$ & $\begin{array}{c}1.2705 \\
(0.8695)\end{array}$ & 0.5509 & $\begin{array}{c}1.3304 \\
(7.8438)^{\star \star \star}\end{array}$ & $\begin{array}{c}-3.9815 \\
(-2.3142)^{\star \star}\end{array}$ \\
\hline 1999 & 0.6251 & $\begin{array}{c}1.5488 \\
(3.8726)^{\star \star \star}\end{array}$ & $\begin{array}{c}-0.3091 \\
(-0.7109)\end{array}$ & 0.8957 & $\begin{array}{c}0.6242 \\
(2.5820)^{\star \star}\end{array}$ & $\begin{array}{c}4.4480 \\
(6.6771)^{\star \star \star}\end{array}$ \\
\hline 2000 & 0.6837 & $\begin{array}{c}1.9538 \\
(7.0797)^{\star \star \star}\end{array}$ & $\begin{array}{c}0.0806 \\
(0.0733) \\
\end{array}$ & 0.7299 & $\begin{array}{c}1.4430 \\
(6.3635)^{\star \star \star}\end{array}$ & $\begin{array}{c}3.4196 \\
(3.5640)^{\star \star \star}\end{array}$ \\
\hline 2001 & 0.4476 & $\begin{array}{c}0.9691 \\
(11.3772)^{\star \star *}\end{array}$ & $\begin{array}{c}0.5900 \\
(1.9680)^{*}\end{array}$ & 0.7559 & $\begin{array}{c}1.3111 \\
(7.5881)^{\star \star \star}\end{array}$ & $\begin{array}{c}0.2595 \\
(1.9415)^{\star}\end{array}$ \\
\hline 2002 & 0.6370 & $\begin{array}{c}0.9382 \\
(4.7758)^{\star \star \star} \\
\end{array}$ & $\begin{array}{c}1.5884 \\
(1.4909) \\
\end{array}$ & 0.8322 & $\begin{array}{c}0.9008 \\
(12.8083)^{\star \star \star}\end{array}$ & $\begin{array}{c}2.0804 \\
(7.7276)^{\star \star \star} \\
\end{array}$ \\
\hline 2003 & 0.5621 & $\begin{array}{c}0.7625 \\
(2.5968)^{\star \star}\end{array}$ & $\begin{array}{c}0.8371 \\
(0.9557) \\
\end{array}$ & 0.5186 & $\begin{array}{c}0.8099 \\
(2.3946)^{\star \star}\end{array}$ & $\begin{array}{c}0.0355 \\
(0.0655) \\
\end{array}$ \\
\hline 2004 & 0.5916 & $\begin{array}{c}1.0949 \\
(6.1230)^{\star \star \star}\end{array}$ & $\begin{array}{c}0.0365 \\
(0.4482)\end{array}$ & 0.8004 & $\begin{array}{c}0.6594 \\
(3.8254)^{\star \star \star}\end{array}$ & $\begin{array}{c}9.2738 \\
(5.3388)^{\star * *}\end{array}$ \\
\hline
\end{tabular}


Table 5 (cont.). Analyses of the value relevance of combined book value and earnings and combined book value and cash flow: multiple linear regression

\begin{tabular}{|c|c|c|c|c|c|c|}
\hline \multirow{3}{*}{ Year } & \multicolumn{3}{|c|}{ Model 4} & \multicolumn{3}{|c|}{ Model 5} \\
\hline & \multicolumn{3}{|c|}{$M P S_{i t}=\alpha_{0}+\alpha_{1} B V P_{i t}+\alpha_{2} C F S_{i t}+\varepsilon_{i t}$} & \multicolumn{3}{|c|}{$M P S_{i t}=\alpha_{0}+\alpha_{1} B V P_{i t}+\alpha_{2} E P S_{i t}+\varepsilon_{i t}$} \\
\hline & $\operatorname{Adj} R^{2}$ & $a_{1}$ & $\alpha_{2}$ & $\operatorname{Adj} R^{2}$ & $a_{1}$ & $\alpha_{2}$ \\
\hline 2005 & 0.5957 & $\begin{array}{c}1.0561 \\
(18.9511)^{\star \star \star}\end{array}$ & $\begin{array}{c}-1.2885 \\
(-5.4323)^{\star \star \star}\end{array}$ & 0.7403 & $\begin{array}{c}1.0886 \\
(3.8917)^{\star \star \star}\end{array}$ & $\begin{array}{c}0.5516 \\
(3.6041)^{\star \star \star}\end{array}$ \\
\hline 2006 & 0.7136 & $\begin{array}{c}1.1939 \\
(7.2936)^{\star \star \star}\end{array}$ & $\begin{array}{c}0.1001 \\
(0.7496)\end{array}$ & 0.7780 & $\begin{array}{c}1.1493 \\
(6.0949)^{\star \star \star}\end{array}$ & $\begin{array}{c}0.2985 \\
(2.4260)^{\star *}\end{array}$ \\
\hline 2007 & 0.7413 & $\begin{array}{c}1.1249 \\
(7.8000)^{\star \star \star}\end{array}$ & $\begin{array}{c}0.3574 \\
(1.0010)\end{array}$ & 0.8012 & $\begin{array}{c}1.0568 \\
(8.2304)^{\star \star \star}\end{array}$ & $\begin{array}{c}0.3076 \\
(2.9570)^{\star \star \star}\end{array}$ \\
\hline 2008 & 0.7042 & $\begin{array}{c}1.1668 \\
(7.3625)^{\star \star \star}\end{array}$ & $\begin{array}{c}0.7877 \\
(1.3792)\end{array}$ & 0.7193 & $\begin{array}{c}1.2351 \\
(5.0606)^{\star * *}\end{array}$ & $\begin{array}{c}0.2804 \\
(2.1911)^{\star *}\end{array}$ \\
\hline 2009 & 0.4010 & $\begin{array}{c}0.4694 \\
(13.7068)^{\star * *}\end{array}$ & $\begin{array}{c}-0.5484 \\
(-4.3264)^{\star \star *}\end{array}$ & 0.6262 & $\begin{array}{c}0.3358 \\
\left((4.2588)^{\star \star \star}\right.\end{array}$ & $\begin{array}{c}1.5188 \\
(2.5584)^{\star \star}\end{array}$ \\
\hline 2010 & 0.7630 & $\begin{array}{c}1.0659 \\
(6.4677)^{\star \star \star}\end{array}$ & $\begin{array}{c}1.2166 \\
(2.5405)^{\star \star}\end{array}$ & 0.7739 & $\begin{array}{c}1.3355 \\
(3.7226)^{\star \star *}\end{array}$ & $\begin{array}{c}0.2330 \\
(1.8218)^{\star}\end{array}$ \\
\hline 2011 & 0.6454 & $\begin{array}{c}0.6659 \\
(8.9564)^{\star \star *}\end{array}$ & $\begin{array}{c}0.7593 \\
(2.3691)^{\star *}\end{array}$ & 0.7199 & $\begin{array}{c}0.7490 \\
(5.5622)^{\star \star *}\end{array}$ & $\begin{array}{c}0.2823 \\
(3.9953)^{\star * \star}\end{array}$ \\
\hline 2012 & 0.6034 & $\begin{array}{c}0.4166 \\
(7.6348)^{\star \star \star}\end{array}$ & $\begin{array}{c}0.2613 \\
(0.7520)\end{array}$ & 0.6775 & $\begin{array}{c}0.2178 \\
(5.3828)^{\star \star \star}\end{array}$ & $\begin{array}{c}3.4214 \\
(9.2523)^{\star \star \star}\end{array}$ \\
\hline 2013 & 0.6756 & $\begin{array}{c}0.6121 \\
(5.4933)^{\star \star \star}\end{array}$ & $\begin{array}{c}1.7860 \\
(3.6787)^{\star \star \star}\end{array}$ & 0.7317 & $\begin{array}{c}0.4448 \\
(9.8307)^{\star \star *}\end{array}$ & $\begin{array}{c}4.8243 \\
(10.1129)^{\star \star \star}\end{array}$ \\
\hline 2014 & 0.6916 & $\begin{array}{c}0.6006 \\
(7.6575)^{\star \star *}\end{array}$ & $\begin{array}{c}0.5506 \\
(0.8691)\end{array}$ & 0.7331 & $\begin{array}{c}0.3770 \\
(3.0785)^{\star \star *}\end{array}$ & $\begin{array}{c}3.9095 \\
(2.7302)^{\star \star *}\end{array}$ \\
\hline Pooled 1994-2014 & 0.4967 & $\begin{array}{c}1.0269 \\
(18.18)^{\star \star \star}\end{array}$ & $\begin{array}{l}0.4154 \\
(2.44)^{\star *}\end{array}$ & 0.5387 & $\begin{array}{c}0.8965 \\
(11.83)^{\star * \star}\end{array}$ & $\begin{array}{c}0.5058 \\
(5.73)^{\star \star \star}\end{array}$ \\
\hline
\end{tabular}

Notes: $* * *, * *, *$ significant at $1 \%, 5 \%$ and $10 \%$, respectively. Numbers in prentices are t-values.

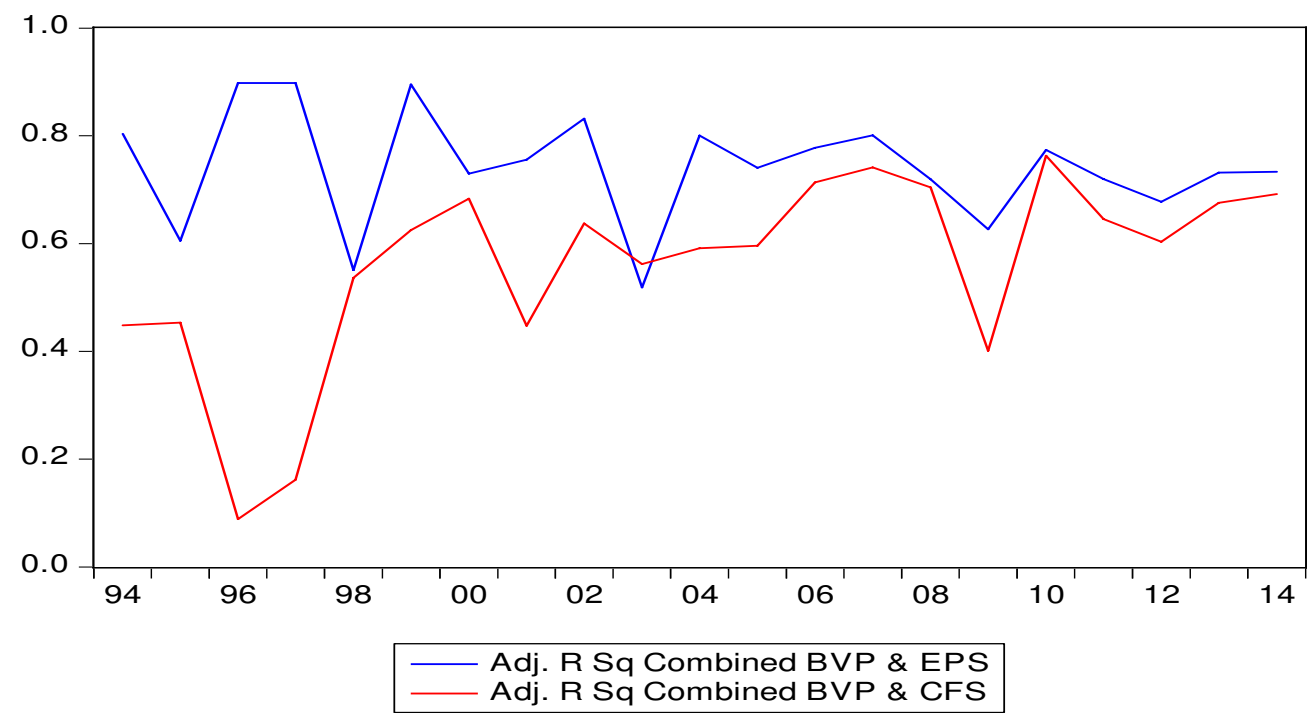

Fig. 2. Graphical view of the value relevance of combined book value and cash flow and the value relevance of combined book value and earnings

Table 5 presents the results of model 4 and 5. Figure 2 presents a graphical analysis which complements the information provided in Table 4. It compares the value relevance of combined book value and cash flow and combined book value and earnings. Combined book value and cash flow explained about $49.67 \%$ of stock price variance in pooled data. This represents a marginal increase of $0.03 \%$ of stock price variance explained by book value in pooled data. Yearly data showed that combined book value and cash flow explained a portion of the variation in stock prices for all the period under study. The highest adjusted R-square recorded was $76.3 \%$ in 2010, while the lowest R-square recorded was $8.87 \%$ in 1996 . Explanatory power of combined book value and earnings had the tendency of growth during 1994 and 1995 but at the end of 1996, a very sharp decline was noticed. The decline in 1996 was followed by an increase in 1997, 1998, 1999 and 2000 but at the end of 2001, a decline in the value relevance of combined book value and cash flow was noticed. The decline was followed again by an increase in the explanatory power of the model and, at the end of 2002, they explained $63.70 \%$ of stock 
price variance. From 2003 to 2007, an inclined pattern of value relevance was observed. The increase in value relevance was followed by a decrease in the explanatory power of the model and, at the end of 2008 and 2009, combined book value and cash flow explained about $70.42 \%$ and $40.10 \%$ of stock variance, respectively. In 2010, there was an increase in the value relevance of accounting information and it reached highest level of $76.3 \%$, but this recovery was interrupted in 2011, where combined book value and cash flow explained about $64.54 \%$ of stock price variance. The explanatory power of the model further decreased to $60.34 \%$ in 2012. During 2013 and 2014, an increase in the explanatory power of the model was noticed. Combined book value and cash flow explained about $67.56 \%$ and $69.16 \%$ of stock price variance. All coefficients of book value were positive in the multiple regression model which is expected. However, some of the coefficients of cash flow were negative which is not expected. The coefficients of cash flow were negative in 1994, 1995, 1999, 2005 and 2009, which is contrary to the researcher's expectation. The overall contribution of cash flow is marginal, re-echoing that cash flow is weakly value relevant and not a good substitute in a valuation model. Combined book value and cash flow are, therefore, value relevant which is consistent with the findings of Kwon (2009).

Model 5 examines the relationship between stock price and combined book value and earnings. Combined book value and earnings explained about $53.87 \%$ of stock price variance. Yearly cross sectional regression showed that combined book value and earnings explained a fraction of the variation in stock prices. The explanatory power of the model reached a high of $89.79 \%$ in 1996 and low of $51.86 \%$ in 2003 . All the coefficients of the model were positive suggesting that book values and earnings are positively correlated with share prices. The explanatory power of accounting variables had a fall tendency in 1994 and 1995 where combined book value and earnings explained about $80.37 \%$ and $60.54 \%$ of stock price variance, respectively. At the end of 1996, the explanatory power of the model increased to a high of $88.79 \%$ and decreased marginally by $0.01 \%$ in 1997 . The explanatory power of combined book value and earnings decreased and increased substantially in 1998 and 1999, respectively. The explanatory power of the model decreased to $72.99 \%$ in 2000 . The explanatory power of combined book value and earnings had the tendency of growth during 2001 and 2002 but, at the end of 2003, a decline in the value relevance was noticed. This decline was again followed by a substantial increase in the value relevance of accounting information and at the end of 2004 combined book value and earnings explained about $80.04 \%$ of stock price variance. The increase was again followed by a decline in the value relevance of accounting information in 2005. During 2006 and 2007, an inclined pattern in the value relevance of accounting information was noticed and, at the end of 2007, combined book value and equity could explain about $80.12 \%$ of the variation in stock prices. During 2008 and 2009, a decline in the value relevance of accounting information was noticed. In 2010, it decreased to $77.39 \%$ meaning that combined book value and earnings explain about $77.39 \%$ of stock price variance. During 2011 and 2012, a decline pattern was observed. This decline was again followed by an increase in the value relevance of accounting information and, at the end of 2013 and 2014, combined book value and earnings contributed to $73.17 \%$ and $73.31 \%$ of stock price variance respectively. Combined book value and earnings are, therefore, value relevant which is consistent with the findings of Mustapha and Jahfer (2013) and Andriantomo and Yudianti (2013).

Hypothesis 1b states that combined value relevance between book value and earnings is greater than that of book value and earnings. When comparing to find out the most value relevant variable, Table 5 and Figure 2 reveal that the adjusted R-square of combined book value and earnings is greater than that of combined book value and cash flow in pooled data. The adjusted R-square of combined book value and earnings is $53.87 \%$, while that of combined book value and cash flow is $49.67 \%$ in pooled data. Yearly data show that the explanatory power of combined book value and earnings is greater than the explanatory power of combined book value and cash flow in all the years under study, but with the exception of the year 2003 where the former and the latter explained $51.86 \%$ and $56.21 \%$ of stock price variance. The results indicate that the value relevance of combined book value and cash flow was only greater than that of combined book value and earnings when the latter was at its lowest point. Generally observed, combined book value and earnings are more value relevant than combined book value and cash flow which is contrary to the findings of Kwon (2009). Hypothesis $1 \mathrm{~b}$ is, therefore, rejected.

Table 6. Analyses of the incremental information content of book values, cash flows and earnings

\begin{tabular}{|c|c|c|c|c|}
\hline Year & $\begin{array}{c}\text { Incremental book value } \\
\text { (BVP \& EPS) }\end{array}$ & $\begin{array}{c}\text { Incremental book value } \\
\text { (BVP \& CFS) }\end{array}$ & Incremental earnings & Incremental cash flow \\
\hline 1994 & 0.1073 & 0.5475 & -0.056 & -0.4111 \\
\hline 1995 & 0.0113 & 0.4630 & 0.2272 & 0.0751 \\
\hline 1996 & 0.0058 & 0.0599 & 0.8179 & 0.0087 \\
\hline
\end{tabular}


Table 6 (cont.). Analyses of the incremental information content of book values, cash flows and earnings

\begin{tabular}{|c|c|c|c|c|}
\hline Year & $\begin{array}{c}\text { Incremental book value } \\
\text { (BVP \& EPS) }\end{array}$ & $\begin{array}{c}\text { Incremental book value } \\
\text { (BVP \& CFS) }\end{array}$ & Incremental earnings & Incremental cash flow \\
\hline 1997 & 0.0107 & 0.1447 & 0.7284 & -0.0079 \\
\hline 1998 & 0.3775 & 0.3531 & 0.0342 & -0.0198 \\
\hline 1999 & 0.0466 & 0.5658 & 0.2691 & -0.0015 \\
\hline 2000 & 0.1503 & 0.472 & 0.0438 & 0.0091 \\
\hline 2001 & 0.3695 & 0.4054 & 0.3174 & 0.0307 \\
\hline 2002 & 0.2606 & 0.4470 & 0.2259 & 0.0178 \\
\hline 2003 & 0.2524 & 0.3864 & -0.0257 & -0.0017 \\
\hline 2004 & 0.0004 & 0.5781 & 0.2071 & 0.044 \\
\hline 2005 & 0.2422 & 0.3997 & 0.1886 & 0 \\
\hline 2006 & 0.3531 & 0.5219 & 0.0644 & 0.008 \\
\hline 2007 & 0.2544 & 0.5834 & 0.0679 & 0.0232 \\
\hline 2008 & 0.1645 & 0.3829 & 0.0383 & -0.2135 \\
\hline 2009 & -0.016 & 0.1479 & 0.0117 & 0.0428 \\
\hline 2011 & 0.2681 & 0.245 & 0.1173 & 0.0043 \\
\hline 2012 & -0.0072 & 0.1479 & 0.0784 & 0.0745 \\
\hline 2013 & 0.1039 & 0.2411 & 0.1306 & 0.0674 \\
\hline 2014 & 0.0842 & 0.3815 & 0.1089 & \\
\hline
\end{tabular}

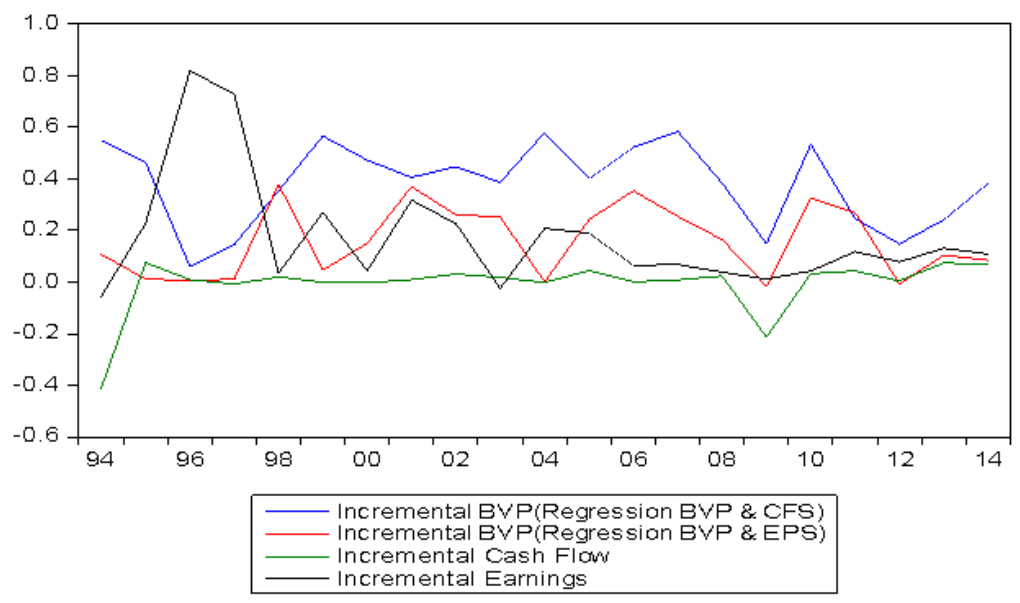

Fig. 3. Graphical view of the incremental information content of book value, cash flow and earnings

Table 6 presents the results of the incremental information content of accounting variables. Figure 3 shows a graphical view of the results provided in Table 6. Book value provides information incremental to the information provided by cash flow by 0.4148 in pooled data. Yearly data showed that book value provides information beyond that which is provided by cash flow in every year. The highest point of incremental book value is 0.5834 in 2007, while the lowest point of incremental book value is 0.0599 in 1996. Incremental book value is quite substantial, as it provides information ranging from 0.1447 and 0.5781 aside its highest and lowest points. This implies that the information content in book values is substantially beyond that provided by cash flow to explain stock price variance. Book value provides information incremental to earnings by 0.2154 in pooled data. Yearly data showed that book value provided information beyond that provided by earnings with the exception of 2009 and 2012, where the information content of book value were 0.016 and 0.0072 , respectively. The highest of incremental book values occurred in 1998 where it provided information incremental to earnings by $37.75 \%$. Earnings provided information incremental to that provided by book value in almost every year except 1994 and 2003. This implies that the information content of earnings are beyond that provided by book value to explain stock price variance except in 1994 and 2003. Incremental earnings are substantially beyond that provided by book values to the extent that it reached a high of 0.8179 in 1996. In pooled data, incremental earnings was around 0.0423. Variability in the information content of cash flow was observed. Cash flow was incremental to book value with the exception of 1994, 1997, 1999, 2000, 2004 and 2009. Incremental cash flow was stagnating at a level of around 0.070 . This is evidence that the incremental information that cash flow provides, if any at all, is marginal. In pooled data, cash flow provides information incremental to book values by $0.03 \%$. 
Hypothesis 1c states that book value provides more information content followed by cash flow and, then, earnings. When comparing the information content of book value, cash flow and earning, the yearly incremental values are used as shown in Table 6 and Figure 3. Yearly data showed that incremental book values are greater than incremental cash flow for all years. Incremental earnings are also greater than incremental cash flow in pooled and yearly data which is consistent with the findings of Daraghma (2010). Yearly data showed that incremental book values (regression with book value and cash flow) are greater than incremental earnings for almost every year except 1996 and 1997. Pooled data showed that incremental book value $(0.4148)$ is greater than incremental earnings (0.0423). Yearly data also showed that incremental book value (regression with book value and earnings) was greater than incremental earnings in thirteen (13) of the twenty one (21) years under investigation. Pooled data showed that incremental book value is greater than incremental earnings which is consistent with the findings of Pathirawasam (2013). Generally observed, incremental book value provide more information content followed by earnings and, then, cash flow. Hypothesis 1c is, therefore, rejected.

Table 7. Analyses of the inclined or decline patterns in the value relevance of book value, cash flow and earnings

\begin{tabular}{|l|c|}
\hline \multicolumn{1}{|c|}{ Variable } & Results \\
\hline \multirow{2}{*}{ Book value } & 0.0119 \\
& $(1.4729)$ \\
\hline \multirow{2}{*}{ Earnings } & -0.0051 \\
& $(-0.7409)$ \\
\hline \multirow{2}{*}{ Cash flow } & 0.0211 \\
& $(7.4338)^{* \star}$ \\
\hline
\end{tabular}

Notes: $* * *, * *, *$ significant at $1 \%, 5 \%$ and $10 \%$, respectively Values in prentices are t-values.

The results indicate the significance of the time trend variable coefficient for cash flow. This shows evidence that the value relevance of cash flow has increased over time. The results also indicate the insignificance of the time trend variable coefficient of book value and earnings. The results show no evidence of the inclined or declined pattern in the value relevance of accounting information of book value and earnings which is consistent with the findings of Pervan and Bartulovic (2014), Andriantomo and Yudianti (2013) and contrary to the findings of Francis and Schipper (1999).

Table 8. Analyses of the inclined and decline patterns in the value relevance of combined book value and earnings and combined book value and cash flow

\begin{tabular}{|c|c|}
\hline Variable & Results \\
\hline Combined book value and earnings & -0.0043 \\
& $(-1.1305)$ \\
\hline
\end{tabular}

\begin{tabular}{|l|c|}
\hline $\begin{array}{l}\text { Combined book value and cash } \\
\text { flow }\end{array}$ & 0.0173 \\
& $(3.3147)^{\star \star \star}$ \\
\hline
\end{tabular}

Note: $* * *, * *, *$ significant at $1 \%, 5 \%$ and $10 \%$, respectively. Values in prentices are t-values.

The results indicate the significance of the time trend variable coefficient for combined book value and cash flow. This shows evidence that the value relevance of combined book value and cash flow has increased over time. The results also indicate the insignificance of the time trend variable coefficient of combined book value and earnings. The results show no evidence of the inclined or declined pattern in the value relevance of combined book value and earnings which is contrary to the findings of Lam, Sami and Zhou (2013).

Table 9. Value relevance of accounting information and earnings management

\begin{tabular}{|l|c|}
\hline \multicolumn{2}{|c|}{ Dependent variable: MPS results } \\
\hline CONSTANT & 3.12 \\
$(6.08)^{* \star *}$
\end{tabular}

Notes: Table 9 presents the results of the value relevance of accounting information and earnings management. $* * *, * *, *$ significant at 1\%, 5\% $10 \%$ level. Values in prentices are $\mathrm{t}$-values. The adjusted R-square for the overall model fit is also reported.

To predict the effect of earnings management on the value relevance of accounting information, some interaction variables are employed. If there is a strong effect of earnings management on the value relevance of accounting information, the coefficients of BVP*EM and EPS*EM are expected to be negative and statistically significant.

It is hypothesized (H3) in this study that, as earnings management increases, the value relevance of accounting information decreases. The results indicate that the coefficients of BVP*EM and EPS*EM were statistically insignificant, but showed different signs. This result is unexpected and it indicates that earnings management has no effect on the value relevance of accounting information. Earnings management is, therefore, neither opportunistic nor efficient. This is consistent with the findings of Fattahi, MoeninAddin and Abtahi (2014), but contrary to the findings of Habib (2004), Jiraporn et al. (2008) and Rezaei (2012). 
Additional analyses: when is earnings management efficient or opportunistic? The current study seeks to highlight the conditions that may be prevalent in other for earnings management to be opportunistic or efficient.The study sample is divided into two, according to size - small and big, and according to asset turnover - high asset turnover and low asset turnover.

Table 10. When is earnings management efficient or opportunistic?

\begin{tabular}{|c|c|c|c|c|}
\hline & Small & Big & L Aturn & $\mathrm{H}$ Aturn \\
\hline$B V P$ & $\begin{array}{c}0.48 \\
(2.63)^{\star \star \star}\end{array}$ & $\begin{array}{c}1.14 \\
(4.02)^{\star \star \star}\end{array}$ & $\begin{array}{c}0.74 \\
(4.37)^{\star \star \star}\end{array}$ & $\begin{array}{c}0.81 \\
(2.89)^{\star \star \star}\end{array}$ \\
\hline EPS & $\begin{array}{c}0.16 \\
(4.95)^{\star \star \star}\end{array}$ & $\begin{array}{c}0.22 \\
(2.64)^{\star \star \star}\end{array}$ & $\begin{array}{c}0.53 \\
(1.88)^{\star}\end{array}$ & $\begin{array}{c}0.28 \\
(2.99)^{\star \star \star}\end{array}$ \\
\hline$B V P^{*} E M$ & $\begin{array}{c}7.46 \\
(2.07)^{\star \star}\end{array}$ & $\begin{array}{c}3.25 \\
(1.50)\end{array}$ & $\begin{array}{c}0.86 \\
(0.85)\end{array}$ & $\begin{array}{c}11.05 \\
(4.55)^{\star \star \star}\end{array}$ \\
\hline$E P S^{*} E M$ & $\begin{array}{c}-0.65 \\
(-3.48)^{\star \star \star}\end{array}$ & $\begin{array}{l}-48.64 \\
(-1.23)\end{array}$ & $\begin{array}{c}-5.16 \\
(-1.86)^{\star}\end{array}$ & $\begin{array}{c}-80.09 \\
(-2.84)^{\star \star *}\end{array}$ \\
\hline$E M$ & $\begin{array}{c}-1.23 \\
(-1.38)\end{array}$ & $\begin{array}{c}1.10 \\
(0.41)\end{array}$ & $\begin{array}{l}-2.66 \\
(-0.89)\end{array}$ & $\begin{array}{c}2.68 \\
(1.06)\end{array}$ \\
\hline$R O A$ & $\begin{array}{c}-0.26 \\
(-1.60)\end{array}$ & $\begin{array}{c}6.22 \\
(2.33)^{\star \star}\end{array}$ & $\begin{array}{c}1.13 \\
(2.21)^{\star \star}\end{array}$ & $\begin{array}{c}0.41 \\
(0.72)\end{array}$ \\
\hline CONSTANT & $\begin{array}{c}1.72 \\
(4.89)^{\star \star *}\end{array}$ & $\begin{array}{c}2.16 \\
(6.79)^{\star \star \star}\end{array}$ & $\begin{array}{c}3.26 \\
(3.97)^{\star \star *}\end{array}$ & $\begin{array}{c}2.66 \\
(6.04)^{\star \star \star}\end{array}$ \\
\hline $\begin{array}{l}\text { Adjusted } R- \\
\text { square }\end{array}$ & 0.3276 & 0.3239 & 0.3356 & 0.3459 \\
\hline
\end{tabular}

Notes: $* * *, * *, *$ significant at the $1 \%, 5 \% 10 \%$ level. Values in prentices are t-values. The adjusted R-square for the overall model fit are also reported. L Aturn and H Aturn are low asset turnover firms and high asset turnover firms, respectively.

As it is apparent from Table 10, the results indicate that the coefficient of BVP*EM are positive and statistically significant, while that of EPS*EM is negative and statistically significant for small companies and high asset turnover companies. This is strong evidence that companies in Singapore manage yearly earnings opportunistically, but, in the long run, (book values) earnings management is efficient. We, therefore, argue that earnings management has an effect on the value relevance of accounting information when companies are small or is high asset turnover companies. We also argue that earnings management within this aforementioned category of companies is likely to be opportunistic when it pertains to the figure earnings and likely to be efficient when it pertains to book values. This argument is quite appealing, because agents are likely to manage earnings in their interest, as it is most probable that earnings figure could be a reference point for their promotion and/or bonuses. This evidence indicates that earnings management is opportunistic in the short run, but efficient in the long run among high asset turnover firms and small companies on the Singapore Stock Exchange.

\section{Conclusion}

The present study has been undertaken to investigate the value relevance of accounting information and how it is impacted by earnings management on the Singapore capital market. The first contribution of the study is that book values are more value relevant followed by earnings and, then, cash flow. We find out that cash flow performs a lessor valuation role, hence, not a good substitute in a valuation model. As a second contribution, the paper compared the value relevance of combined book value and earnings and combined book value and cash flow. We find that combined book value and earnings are more value relevant that combined book value and cash flow. This is as a result of marginal contribution of cash flow to the model reiterating about the lesser valuation role it plays. We also find that book value is more incremental followed by earnings and then cash flow. As a third contribution, we investigated the inclined and declined patterns in the value relevance of accounting information. We find that the value relevance of cash flow and combined book value and cash flow has increased over time. However, the results showed no evidence of the inclined or declined patterns in the value relevance of book value, earnings and combined book value and earnings. Overall, even though cash flow does not perform well in a valuation role, we gain a full understanding that its explanatory power in the model is getting better with time. Finally, we find that earnings management has no effect on the value relevance of accounting information on the entire sample. Earnings management is, therefore, neither efficient nor opportunistic as reported by Rezaei (2012) and Jiraporn et al. (2008). This may be as a result of the good corporate governance that exists in Singapore. Further analyses indicate that earnings management is opportunistic in the short run, but efficient in the long run among high asset turnover firms and small companies on the Singapore Stock Exchange.

Several limitation of the paper should be noted. Limitation of the scope of the paper as a result of nonavailability of data for earlier periods. The investigation could be done by focusing on a longer time period. Another limitation of this paper is that it only employs Ohlson's (1995) model. Further studies may be conducted using the portfolio returns approach or the return model of the regression variation approach to provide an in-depth understanding and robust the results of this study. Another limitation is that the paper only employed book value, earnings and cash flow. Further studies could be conducted exploring variables such as residual earnings and dividends. 


\section{References}

1. Amir, E. \& Lev, B. (1996). Value-relevance of nonfinancial information: the wireless communication industry, Journal of Accounting and Economics, 22(1-3), pp. 3-30.

2. Andriantomo \& Yudianti, N. (2013). The Value Relevance of Accounting Information at Indonesia Stock Exchange. The 2013 IBEA, International Conference on Business, Economics, and Accounting, Bangkok.

3. Bernard, V.L. (1993). Earnings quality, book value and the state of financial statement analysis. (S. Buller, Ed.) In Earnings Quarterly, pp. 174-183.

4. Brown, S., Lo, K. \& Lys, T. (1999). Use of R squared in accounting research: measuring changes in value relevance over the last four decades, Journal of Accounting and Economics, 28, pp. 83-115.

5. Chen, K. \& Yuan, H.Q. (2001). Earnings management and capital resource allocation: evidence from China's accounting based regulation of right issues. Working Paper. Hong Kong University of Science and Technology.

6. Choi, H.S. \& Jang, S.C. (2006). The relative value relevance of earnings and cash flow measures in each life-cycle stage, Korean Management Review, 35(5), pp. 1339-1360.

7. Collins, D., Maydew, E. \& Weiss, I. (1997). Changes in the value relevance of earnings and book values over the past forty years, Journal of Accounting and Economics, 24, pp. 39-67.

8. Daraghma, Z. (2010). The and incremental information content of earnings and operating cash flows: Empirical evidence from Middle East, the case of Palestine, European Journal of Economics, Finance and Administrative Sciences, 22, pp. 123-135.

9. Deegan, C. (2009). Financial Accounting Theory (3rd ed.). Australia: McGraw Hill.

10. Deloitte. (n.d.). IAS Plus. Retrieved September 20, 2015, from Singapore: http://www.iasplus.com/en/ jurisdictions/asia/Singapore.

11. Fattahi, R., MoeinAddin, M. \& Abtahi, Y. (2014). Impact of earnings management on value relevance of accounting information of the firms listed on the Tehran Stock Exchange, Interdisciplinary Journal of Contemporary Research in Business, 6(2), pp. 378-392.

12. Foundation, IFRS. (2014, September 8). IFRS Application around the World Jurisdictional Profile: Singapore. Retrieved from IFRS: http://www.ifrs.org/Use-around-the-world/Documents/Jurisdiction-profiles/SingaporeIFRS-Profile.pdf.

13. Francis, J. \& Schipper, K. (1999). Have financial statements lost their relevance? Journal of Accounting Research, 37, pp. 319-352.

14. Habib, A. (2004). Impact of earnings management on value relevance of accounting information: Empirical evidence from Japan, Managerial Finance, 30(11), pp. 1-15.

15. Healy, P. \& Palepu, K. (2001). Information asymmetry, corporate disclosure, and the capital markets: a review of empirical disclosure literature, Journal of Accounting and Economics, 31, pp. 405-440.

16. Hejazi, R., Jafari, M. \& Karimi, A. (2011). The information content of accounting variables in companies listed on the Tehran Stock Exchange (TSE), Business Management Dynamics, 1(2), pp. 32-38.

17. Hung, M. (2001). Accounting standards and value relevance of financial statements: an international analysis, Journal of Accounting and Economics, 30, pp. 401-420.

18. Jiraporn, P., Miller, G.A., Yoon, S.S. \& Kim, Y.S. (2008). Is earnings management opportunistic or beneficial? An agency theory perspective, International Review of Financial Analysis, 17(3), pp. 622-634.

19. King, R.D. \& Langli, J.C. (1998). Accounting diversity and firm valuation, The International Journal of Accounting, 33, pp. 529-567.

20. Kwon, G.-J. (2009). The Value Relevance of Book Values, Earnings and Cash Flows: Evidence from Korea, International Journal of Business Management, 4, pp. 28-42.

21. Lam, K.C., Sami, H. \& Zhou, H. (2013). Changes in the value relevance of accounting information over time: Evidence from the emerging market of China, Journal of Contemporary Accounting and Economics, 9, pp. 123-135.

22. Musthafa, S.L. \& Jahfer, A. (2013). Value Relevance of Accounting Information: Evidence from Sri Lanka, Proceedings of the Third International Symposium, SEUSL. Oluvil, Sri Lanka.

23. Nilsson, H. (2003). Essays on the value relevance of financial statement information. Working Paper, Umea Universitet.

24. Ohlson, J.A. (1995). Earnings Book Value and Dividends in Equity Valuation, Contemporary Accounting Research, 11(2), pp. 661-687.

25. Pathirawasam, C. (2013, June). The Value Relevance of earnings and book value: tThe importance of ownernership concentration and firm size, Journal of Competiveness, 5(2), pp. 98-107. doi:10.7441/joc.2013.02.07.

26. Pervan, I., \& Bartulovic, M. (2014). Value relevance of Accounting Informatio: Evidence from South Eastern European Countries, Economic Research-Ekonomska Istrazivanja, 27(1), pp. 181-190. doi:10.1080/1331677X.2014.947132.

27. Qiu, A. (2004). Audit quality and earnings management- empirical evidence from China's Stock Market (Doctoral thesis, The Hong Kong Polytechnic University, Hung Hom, Hong Kong).

28. Rezaei, F. (2012). Efficient or opportunistic earnings management with regards to the role of firm size and corporate governance practices, Interdisciplinary Journal of Contemporary Research in Business, 3(9), pp. 1312-1322.

29. Scott, W.R. (2000). Financial Accounting Theory (2nd ed.). Toronto: Prentice Hall.

Notes: Since earnings figure pertains to an accounting year, this study labels it short run, but labels book value as "long run", since it covers at least an accounting year. 